\title{
Measuring the Malindo Airline Passenger's Satisfaction
}

\author{
Zakaria Wahab ${ }^{1}$, Inda Sukati ${ }^{2}$ \& Lee Hua $\mathrm{Li}^{2}$ \\ ${ }^{1}$ Fakultas Ekonomi Jurusan Manajemen, Universitas Sriwijaya, Palembang, Indonesia \\ ${ }^{2}$ Faculty of Management, Department of Business Administration (Marketing), Universiti Teknologi Malaysia, \\ Malaysia \\ Correspondence: Inda Sukati, Faculty of Management, Department of Business Administration (Marketing), \\ Universiti Teknologi Malaysia, Malaysia. E-mail: indasukatiutmjb@gmail.com
}

Received: February 28, 2015 Accepted: March 23, 2015 Online Published: June 5, 2015

doi:10.5539/ass.v11n18p233 URL: http://dx.doi.org/10.5539/ass.v11n18p233

\begin{abstract}
Quality of service has become a tool to improve the passenger's value that lead to their satisfaction level and retains loyalty. This study conducted in evaluating the Malindo Airline passenger's satisfaction of Low Cost Carrier (LCC) in Malaysia. The purpose of this research is to evaluate the level of quality of service provided by Malindo Airline. In addition, the aim of this study is to identify the impact of quality of service and Malindo Airline passenger's satisfaction. The sample for this research is the passenger's of Malindo Airline in Kuala Lumpur. Convenience sampling was used in this study. Questionnaires have been distributed to 200 respondents in Subang Jaya Airport and KLIA 2. SPSS version 18.0 was used to analyse the data collected. Descriptive analysis, Pearson correlation, multiple regression, model are used to test on the impact of quality of service on Malindo Airline passenger's satisfaction. The results showed that there is a positive correlation between quality of service and Malindo Airline passenger's satisfaction among passenger's of Malindo Airline.
\end{abstract}

Keywords: quality of service, Malindo Airline passenger's satisfaction, SERVQUAL

\section{Introduction}

Nowadays, airplanes have become an important transportation in our life. The presence of airplane helps to save the time and shorter the distance to travel from one place to another. Airline industry made up of two types of operation which are Full Cost Carriers and Low Cost Carriers.

The main advantage of low cost carrier to the passenger's would be the low price offered. According to Kotler P. (2010), pricing decisions are vital for the marketing organisation and the courtesy of marketer to the price is as important as the courtesy of marketer given to the marketing activities. Therefore, MALINDO airline could have pricing competitive advantage compared to the full cost carrier (FCC) as it provides a lower price than FCC.

Better quality of service is necessary for MALINDO Airline Company to satisfy their passengers to retain competitive. Malindo Airline passenger's satisfaction refers to customer's perception that measure the services they expected to receive and the actual services they received (Kotler \& Armstrong, 1999). A satisfied customer will create positive word of mouth of the airline company. MALINDO airline as a LCC, they provided personal TV for in-flight entertainment and comfortable legroom in the plane which will be a competitive advantage for the company. Therefore, understanding passengers' needs and delivering high quality services will resulted in the Malindo Airline passenger's satisfaction and retain the customer's loyalty.

As a latest Low Cost Carrier (LCC) in Malaysia, Malindo airline have to face a few of competitors that have been operated in Malaysia earlier. Other than Malindo airline, there are other LCC in Malaysia which are AirAsia as the main competitor and Firefly. The market has become competitive as the LCC using the low pricing method to attract their target customer.

Aside from the low price that offered by the LCC, quality of service is a factor that determine the customer preference in choosing airline's company for their flight. Passengers often choose the airline based on their past experience with the flight, whether they were satisfied or dissatisfied with the services provided by the airline.

The main objective of this research is to examine the relationship between quality of service and Malindo Airline passenger's satisfaction. To achieve the research objective, this paper focused on the following research questions: RQ1: What is the relationship between tangible and Malindo Airline passenger's satisfaction? RQ2: 
What is the relationship between reliability and Malindo Airline passenger's satisfaction? RQ3: What is the relationship between responsiveness and Malindo Airline passenger's satisfaction? RQ4: What is the relationship between assurance and Malindo Airline passenger's satisfaction? RQ5: What is the relationship between empathy and Malindo Airline passenger's satisfaction?

\section{Literature Review}

\subsection{SERVQUAL}

Currently, most of companies focus on maintaining and improving quality of serviceto survive in such a competitive business world (Reichheld \& Sasser, 1990). Many Scholars have focused on their study on the concept of quality of services for many of years, but still no consensus achievement in terms of how to truly define quality of services (Cronin \& Taylor 1992). The concept of quality of services can be elaborate from several perspectives and aspects due to the fact that it is perceived as a multi-dimensional construct requiring multiple perceptual measures to be completely conceptualized (Parasuraman, Zeithaml, \& Berry, 1985; Lin, 2010).

Quality of service is the subjective perception of customers generate by comparing their service expectation and perceived service $(\mathrm{Yu}, 2002)$. This concept in line with Parasuraman, Zeithamal \& Berry (1985) "Quality of services is defined as the difference of customers' pre-service expectation and post service perception". If quality of services matching with customer pre-service expectation, the service has pre-perceived quality.

Service is activities of individuals or groups provide for their organization benefit provides for another organization. Service is intangible concept and without ownership transfer. It can be a sub-product of a product, also can be independent. Customers' perception to service heavily depends on quality of services (Kotler, 1996; 1999). Quality of services is the consistent level of Malindo Airline Passenger's satisfaction overall assessment to a service they perceived (Weng, 1998; Su, 2000).

Quality of services is to match and exceed customers' expectation on products and services. It is the main key for business to attract customers and maintain long-term customer relations. It can also improve efficiency and avoid unnecessary resources waste (Wang, 2002; Liang, 2001). Source: extracted from Lin, (2003); Ho (2004).

Most previous and current researchers agreed that quality of services is assessed by customers (Brown, 1993; HO \& Su, 1995; Weng, 1998). Quality of services is the subjective assessment customers make after they receive service.

According to the many scholars show that quality of services is the subjective assessment customers make after they receive services. It is not decided by the Malindo airlines. Compare to product quality, quality of services is difficult to assess. Before assessing quality of services, different factors of quality of services provided by former researchers needs to be discussed as follow:

Sasser, Olsen, \& Wyckoff (1978): Seven quality factors that should be used to evaluate the quality of services: (1). Security: Safety of customer and their belongings. (2). Consistency: Services should be standardized. It should not change with customers, time and locations. (3). Attitude: Service providers' psychological condition when they interact with customers. Politeness and helpfulness are two examples of attitude. (4). Completeness: Service and equipment should be complete. (5). Condition: Service can be adjusted to meet different individual needs and wants. (6). Availability: Service should be available to customers in terms of time and space. (7). Timing: Service is completed within customers' expected timeframe.

Quality of services includes attitude of service provider, service providers' consideration, service content, empathy, service speed, and sincerity of problem solving, listening skills and responsibility (Mitra, 1993; Chen, 1995). Factors used to assess services should include physical quality, interaction quality, content quality, process quality and result quality (Johnson, Tsiros, \& Lancioni, 1995; Lehtinen \& Lehtinen, 1991). It is different from the five factors Parasuraman mentioned in his research in 1988, and DabHolkar et al. (1996) defined the quality of services includes reliability, intangibility and the interaction between customers and service providers. Rust \& Oliver (1994) pointed out for three factors of quality of services: 1. Interaction between customers and service providers. 2. Quality of the environment where the service is provided. 3. Result quality: customers' assessment on the results of services.

American Marketing Association (AMA) found five factors that are used to assess quality of services: credibility, assurance, empathy, responsiveness and equipment. Ho (2004) mentioned five factors that influence quality of services of sport clubs: 1. Service provider: the overall performance of service provider, such as manner, attitude, appearance and empathy 2. Convenience: the location of swim clubs, their operation schedule and equipment 3. Equipment and atmosphere: the main and affiliated equipment and the overall atmosphere 4. System: 
maintenance of equipment, club programs and management of customer data. 5. Corporate image: The image of the club and how clubs represent customer status.

Different researchers have provided different factors to evaluate customer service. This study defined reliability, responsiveness, assurance, empathy as factors of assessing quality of services. Parasuraman, Zeithamal, \& Berry (P.Z.B.)'s SEVQUAL rubrics.

SERVQUAL rubric is the most commonly used quality of services assessment form. It is also the first systematic rubric form. The following is the ten factors they developed: (a). Accessibility: Service is accessible. (b). Credibility: Honesty, reliability and dependability: Customers are the most important. (c). Responsiveness: It includes the willingness service providers are when providing service, how they respond to a request and their preparation before providing a service. (d). Competence: Whether or not service providers have expertise and skills necessary. (e). Courtesy: Service providers' attitude, respectfulness, empathy and manner towards customers. (f). Communication: Service providers should be able to speak in customers' tones and to listen to their complaints and suggestions. (g). Reliability: Whether or not business can keep their promises to customers and can be dependable. (h). Tangibility: All the equipment that is affiliated to the service. (i). Knowing Customers: Know customers needs and wants (j). Security: protect customers from danger, risks and physical and mental injuries. Parasuraman, Zeithamal, \& Berry did further study on evaluation factors for quality of services and refined the ten factors to five major factors: (a). Tangibility: Service facility, equipment and appearance of service providers. (b). Reliability: The ability to provide guaranteed service to customers. (c). Responsiveness: The willingness service providers are in helping customers. (d). Assurance: Service providers have the expertise and skills necessary to provide services. (e). Empathy: Service providers care about and also are able to pay attention to customers' individual needs and wants. In this study, Quality of services is a subjective evaluation of quality of services provided by Malindo airlines. This study also uses a five dimensions quality of services.

\subsection{Malindo Airline Passenger's Satisfaction}

The concept of customer satisfaction (Malindo Airline Passenger's satisfaction) was first proposed by Cardozo (1965). It has now been studied for many years, mainly in the field of consumer behaviour and service marketing, and considered one of the most important factors to affect the success of business organizations (Cronin \& Taylor, 1992).

The concept of customer satisfaction (Malindo Airline Passenger's satisfaction) has been defined in various ways, but no consensual definition has been reached (Hung-Yung Lin, 2010). Most researchers defined the notion of consumer satisfaction as a response to an evaluation process based on the disconfirmation of an expectations paradigm in which three discrepancies were identified: (1) positive disconfirmation, where the performance of service exceeds customer expectation, (2) confirmation, where performance of service equals to customer expectation, and (3) negative disconfirmation, where the performance of service does not meet or falls below customer expectation (Oliver \& DeSarbo, 1988).

Anderson, Fornell and Lehman (1994) reviewed the various approaches of conceptualizing Malindo Airline Passenger's satisfaction proposed by different researchers and distinguished two different conceptualizations of Malindo Airline Passenger's satisfaction: transaction-specific and cumulative (Boulding, Staelin, Kalra, \& Zeithaml, 1993). The transaction-specific perspective of Malindo Airline Passenger's satisfaction suggested that customer satisfaction (Malindo Airline Passenger's satisfaction) is considered tobe a subjective evaluation of a specific purchase experience formed after the occurrence of buying behaviour (Oliver 1977, 1980). On the other side, from cumulative perspectives of Malindo Airline Passenger's satisfaction, it inferred that Malindo Airline Passenger's satisfaction is viewed as an evaluative judgment of the overall purchasing experience and product or service excellence overtime (Johnson \& Fornell, 1991). Cumulative satisfaction is a more long-term measure compared to transaction-specific satisfaction, which focuses mainly on customers' immediate reactions or emotions to service or product (Lin, 2010).

The concept of customer satisfaction (Malindo Airline Passenger's satisfaction) has been defined in various ways. Researchers have approached it from cognitive, psychological, affective, or physiological perspectives to conceptualize the idea of Malindo Airline Passenger's satisfaction but no consensus has been reached. However, no matter what approach the researchers used to conceptualize customer satisfaction (Malindo Airline Passenger's satisfaction), most of them were in accordance with the principles of the disconfirmation of expectations paradigm (Oliver \& DeSarbo, 1988), which proposed that Malindo Airline Passenger's satisfaction is the result of the comparison between the actual performance of the product or service and the prior 
expectations about the performance of the product or service. This is to say that if the prior expectations are met or exceeded, then customer satisfaction (Malindo Airline Passenger's satisfaction) will occur (Lin, 2010).

\subsection{Relationship between Quality of Service and Malindo Airline Passenger's Satisfaction}

The concepts of quality of services and Malindo Airline Passenger's satisfaction are two important constructs which lead to better understanding of customer behaviours and help business practitioners create effective strategies to enhance customer loyalty (Iacobucci, Ostrom, \& Grayson, 1995). The relationship between quality of services and customer satisfaction (Malindo Airline Passenger's satisfaction) has received a great deal of interest by researchers; however, there are varying opinions regarding the relationship between the two constructs.

Iacobucci, Ostrom, and Grayson (1995) argued both quality and satisfaction can be defined as the comparison between prior expectation and actual performance, so they are interchangeable terms in some circumstances, as if the two are essentially one construct. On the other hand, Oliver (1997) and Tian-Cole and Crompton (2003) suggested customer satisfaction (Malindo Airline Passenger's satisfaction) includes cognitive and affective evaluations, whereas quality of services primarily concentrates on cognitive evaluations; therefore, the construct of customer satisfaction (Malindo Airline Passenger's satisfaction) is a broader concept than quality of services (Kouthouris \& Alexandris, 2005).

Some researchers proposed that the constructs of quality of services and customer satisfaction (Malindo Airline Passenger's satisfaction) are strongly related. For instance, Cronin and Taylor (1992) conducted research in four industries - banking, fast food, dry cleaning, and pest control-for the purpose of identifying the interrelationship between quality of services, customer satisfaction (Malindo Airline Passenger's satisfaction), and purchase intentions. The results showed that quality of services was the antecedent of customer satisfaction (Malindo Airline Passenger's satisfaction) and had more effect on customer satisfaction (Malindo Airline Passenger's satisfaction) than did purchase intention (Cronin \& Taylor, 1992). The constructs of quality of services and Malindo Airline Passenger's satisfaction are, to a certain extent, highly related

Woodside, Frey, and Daly (1989) conducted a similar study in the hospital industry, and their study results also gave support to the idea that quality of services and customer satisfaction (Malindo Airline Passenger's satisfaction) are two related constructs. Further, Oliver (1993) proposed the Satisfaction/Quality of services model to demonstrate the relationship between the two constructs.

In the Satisfaction-Quality of services model, Oliver (1993) postulated that quality of services is determined by the comparison between the ideals and perceived product or service performance regarding quality dimensions. Satisfaction is determined by the prior expectations and perceived product or service performance regarding both quality and non-quality dimensions, and satisfaction is the consequence of quality of services (Oliver, 1993).

\section{Methodology}

\subsection{Research Design}

Design of this research developed to answer research question and examined research hypothesizes. This research was primarily a correlation design that examines the relationship between service of quality provided by Malindo Airline service and Passenger's satisfaction.

\subsection{The Conceptual Framework}

Based on the review of literature, the conceptual framework could be proposed as follow:

Generally, this research will study on the dimensions of quality of service (tangible, reliability, responsiveness, empathy and assurance) and Malindo Airline passenger's satisfaction. According to the conceptual model, the independent variables are the dimensions of quality of service (tangible, reliability, responsiveness, empathy and assurance) whereas the dependent variables are Malindo Airline passenger's satisfaction.

\subsection{Hypotheses}

Based on Literature review discussion above, the following hypothesis was proposed:

$\mathbf{H}_{\mathbf{1}}$ : There is a positive relationship between service tangibility and Malindo Airline passenger's satisfaction.

$\mathbf{H}_{2}$ : There is a positive relationship between service reliability and Malindo Airline passenger's satisfaction.

$\mathbf{H}_{3}$ : There is a positive relationship between service responsiveness Malindo Airline passenger's satisfactions.

$\mathbf{H}_{4}$ : There is a positive relationship between service assurance and Malindo Airline passenger's satisfaction.

$\mathbf{H}_{5}$ : There is a positive relationship between service empathy and Malindo Airline passenger's satisfaction. 


\subsection{Population and Sampling Method}

The population of this research was the passenger's who have flight experience with MALINDO airline in Kuala Lumpur. The table for selecting the sample size from a population by Krejcie and Morgan (1970) was not suitable as the population of MALINDO passenger's are undefined. 200 questionnaires were distributed to achieve the $10 \%$ margin error in this study.

\subsection{Data Collection}

This study was using both primary and secondary data to achieve the accuracy and precision of the research's findings. Collecting data methods were used to identify the different information and sources that had been used in the study.

\subsubsection{Primary Data}

Primary data was derived from the independent variables and dependent variables. The independent variables in this study is quality of service (tangible, reliability, responsiveness, assurance and empathy), whereby the dependent variable in this study is passenger's satisfaction. Other than that, questionnaire forms were distributed to those who had experience MALINDO's flight. Through questionnaire distribution, information of the users such as demographic information, factors that affect their satisfaction and loyalty towards MALINDO airline can be obtained.

\subsubsection{Secondary Data}

Secondary data included theory, definitions, facts, statistics, reports and opinions from the previous research that have been conducted. In this study, secondary data was used in constructing the proposed model framework and form its relationships with the customer loyalty towards MALINDO airline.

There are a few media that can be used as secondary data such as journals, magazines, newspaper, internet, reference books and archival records. Secondary data can be obtained quickly and easily compared to primary data and it is less costly than primary data. Yet, secondary data can only be used to support the researchers in creating conclusion and provide insight knowledge about this study.

\subsection{Research Instrument}

Research instrument is vital in developing a questionnaire. In order to avoid misunderstanding of the respondents, the questionnaire should be developed by using simple and easy English language. Thus, a precise, short and direct well-defined sentence were used in the questionnaire for the convenience of respondents to answer the questions within a short time correctly and accurately.

Table 1. Instruments for measuring dimensions of quality of service

\begin{tabular}{|c|c|c|c|}
\hline Construct & No & Original sentence & Propose sentence \\
\hline Tangible & 1 & The airline has new planes. & The planes of the airline are new and modern looking. \\
\hline Eng Ai Jia & 2 & The seats in the planes were comfortable. & The plane has comfortable seats. \\
\hline and Lee & 3 & Quality of in-flight environment and airport facilities. & The in-flight environment is superior. \\
\hline $\begin{array}{l}\text { SheeCheae } \\
(2012) \text {. }\end{array}$ & 4 & Food and beverages in the planes & Food and beverages provided during the flight were good. \\
\hline Reliability & 5 & Provide the service at the time of promised & The flight schedule is always on time. \\
\hline \multirow{2}{*}{$\begin{array}{l}\text { K. Aydin } \\
(2012)\end{array}$} & 6 & Perform the service right the first time & The airline provides consistent service all the time. \\
\hline & 7 & Insist on error free records. & The airline go through inspections and announcement. \\
\hline Responsivene & 8 & Flight ticket can be easily booked online. & Easy to book the flight ticket online. \\
\hline \multirow{2}{*}{$\begin{array}{l}\text { Ss. Aydin } \\
(2012)\end{array}$} & 9 & Customers will always be willing to help passenger's. & The personnel in-flight are willing to help. \\
\hline & 10 & Customers will give prompt service to passenger's & $\begin{array}{l}\text { The in-flight personnel gives prompt handling of requests } \\
\text { and complaints. }\end{array}$ \\
\hline \multirow{3}{*}{$\begin{array}{l}\text { Assurance } \\
\text { K. Aydin } \\
(2012)\end{array}$} & 11 & The behaviour of customers will instill confidence in & The behaviour of in-flight personnel and staff gives \\
\hline & 12 & $\begin{array}{l}\text { passenger's. } \\
\text { Customers will have the knowledge to answer } \\
\text { passenger's' questions. }\end{array}$ & $\begin{array}{l}\text { confidence to passenger's. } \\
\text { Airline personnel and staff have knowledge to answer } \\
\text { questions. }\end{array}$ \\
\hline & 13 & Passenger's feel safe in transactions. & You feel safe in the airline. \\
\hline \multirow{3}{*}{$\begin{array}{l}\text { Empathy } \\
\text { K. Aydin } \\
(2012)\end{array}$} & 14 & Have customer's best interests at heart. & $\begin{array}{l}\text { The in-flight personnel and staff have customer's best } \\
\text { interests at heart. }\end{array}$ \\
\hline & 15 & Customers give passenger's personal attention & $\begin{array}{l}\text { The airline personnel and staff gives customer personal } \\
\text { attention. }\end{array}$ \\
\hline & 16 & Understand the specific needs of passenger's & $\begin{array}{l}\text { The airline personnel understands the specific needs of } \\
\text { passenger's. }\end{array}$ \\
\hline
\end{tabular}


A set of questionnaire was designed based on the objective of this study. Questionnaire forms was distributed and also online distribution to the respondents that had flight experience with MALINDO airline in Malaysia. The questionnaire will help to gain treasured information which helps to answer the research questions and achieve the objectives which had set by the researcher after that data was analysed.

The questionnaire consists of 28 items in measuring independent variables and dependant variables. All the questions are based on close-ended format. The questionnaire consist of 1 filter question to make sure the right respondents were targeted. The questionnaire was divided into four sections. Section A of the questionnaire contains questions to obtain respondent's demographic information and flight experience with MALINDO airline.

Section B contains the questions that would answer the measurements of quality of service provided by MALINDO airline towards the respondents. There are total of 16 different types of questions in this section.

Section C contains the questions that would determine the respondent's satisfaction towards services provided by MALINDO airline. There are total of 3 questions in this section.

Table 2. Instrument for measuring passenger's satisfaction

\begin{tabular}{cccc}
\hline Sources & No & Original Sentence & Proposed Sentence \\
\hline $\begin{array}{c}\text { Halil Nadiri, } \\
\text { Kashif (2008) }\end{array}$ & 18 & $\begin{array}{c}\text { My satisfaction with the Malindo airline has } \\
\text { increased }\end{array}$ & $\begin{array}{c}\text { I am satisfied with the services provided by the airline and } \\
\text { satisfaction with the airline has increased. } \\
\text { improved }\end{array}$ \\
& 19 & $\begin{array}{c}\text { I now have positive attitude towards the } \\
\text { Malindoairline company }\end{array}$ & I am impressed with MALINDO airline. \\
\end{tabular}

\subsection{Validity and Reliability of the Research}

Validity was the level of which a review accurately reflects the specific idea that it attempts to determine (Creswell, 2002). Three types of validity are addressed here: content validity; construct validity, and criterion-related validity. Content validity is based on the extent to which a measurement reflects the diversity of meanings included within the concepts.

Reliability is the extent to which any measuring procedure yields the same result in repeated trials under similar condition (Creswell, 2002). Providing questions, which are clear, about what respondents are being asked, can increase the reliability. The questionnaire should be designed such that the respondents are familiar with the questions and the questions themselves are relevant to the respondents.

\subsubsection{Factor Analysis}

The Kaiser-Meyer-Olkin (KMO) was used to measure the sampling adequacy test and Bartlett; $\mathrm{s}$ test of Sphericity was performed to confirm the suitability of the data for factor analysis. A high KMO value (close unity or $>0.6)$ and a small p-value for the Bartlett's test (p-value $<0.05)$ were desired in order to validate the relationships of the variables (Hair et al., 2006). Overall, KMO should be 0.6 or higher to continue with factor analysis, if it is lower than 0.6 , the indicator variables with the lowest individual KMO statistic values, until KMO overall rises above 0.6.

Factor analysis was used in this study to examine the construct of the context of customer loyalty towards MALINDO airline. It runs on all the items in quality of service, passenger's satisfaction and customer loyalty. Factor analysis also an experimental tool to test the theoretical data structures. Thus, unnecessary dimensions was removed from the instrument.

\subsubsection{Reliability Test}

Reliability of the instrument plays a vital role in gaining a success of a research. Therefore, the instrument used in a research must reach a certain level of reliability to make the research successful. According to Hair (1998), the primary idea for measuring reliability that made use of the consistency among the variables in a summated scale is internal consistency. Hence, in order to get higher reliability of test, researcher must ensure the present of high consistency in the measurement of this study.

In this study, Cronbach's Alpha Test was used to test the reliability for both independent and dependant variables. Cronbach's Alpha test has been often used in testing the reliability coefficient assessing the consistency of the entire scale. As refer to Hair et al. (1998), the lower limit of acceptability estimation exists when reliability estimated was between 0.6 and 0.7 . 


\subsection{Examining the Data of the Variables}

An examination was conducted to identify whether underlying assumptions are met in order to apply correlation and regression analysis before the use of multiple regression analysis. Assumptions were tested by using methods as suggested by Hair et al. (1998). The three diagnostic tests were carried out to meet all the three assumptions which are linearity, normality and multiconllinearity.

\subsection{Data Analysis}

Data analysis is known as a process of interpretation of data collected in this research to draw a conclusion which were acceptable and understandable. Statistical Package for Social Science (SPSS) software was used to examine and analyse the raw data that were collected from the targeted respondents in this study. The reason SPSS was selected is because SPSS has a wide array of application for practitioner to do the quantitative analysis. All the data collected from questionnaire was key in to SPSS software to get the result for data analysing.

\subsubsection{Descriptive Analysis}

There are many techniques that can be used to clarify and explain descriptive statistic, such as mean and standard deviation, percentage, and frequency. In this study, frequency and percentage were chose to be used in the research to explain deeply on descriptive statistic. The respondent profile was analysed by using the percentage and frequency.

The demographic of the respondents was conveyed by using the frequencies procedure and the statistical method used was percentage. The demographic factors that reported were gender, educational level and occupation. Later, the respondents were asked on the experiences, satisfaction and loyalty to MALINDO Airline.

\subsubsection{Pearson's Correlation}

The purpose of Pearson Correlation is to test the hypothesis of the studies. By using Pearson Correlation, the research can identify whether there has a significant relationship between the dimensions of quality of service (tangible, reliability, responsiveness, assurance and empathy) with customer loyalty in MALINDO airline. Furthermore, the relationship of passenger's satisfaction and customer loyalty will also be tested.

Generally, Pearson Correlation coefficient $(r)$ ranges between positive and negative. Positive and negative sign represents the relationships between variables tested are either in the parallel or reverse form. Pearson Correlation Coefficient is $0.196(\alpha=0.05)$. If the absolute value of the computed $r$ is above $\alpha$, it shows that it has correlation between the two variables. If the absolute value, $r$ is close to zero or less than $\alpha$, it implies no relationship between the two variables.

\subsubsection{Multiple Regressions}

Multiple regressions can be conducted if the relationship exists between dimensions of quality of service (tangible, reliability, responsiveness, assurance and empathy) with passenger's satisfaction towards customer loyalty in MALINDO airline. Further analysis can be perform by using multiple regression method to identify the directional of the relationship between each other. Passenger's satisfaction and customer loyalty was the dependant variable while quality of service was the independent variable in this research.

The value of R-Square, $\left(\mathrm{R}^{2}\right)$ was highlighted in the model summary table. $\mathrm{R}^{2}$ also known as the coefficient of determination, which is a frequently used statistic to evaluate model fit. Therefore, the larger the $\mathrm{R}^{2}$ obtained in the study, the more significant of the quality of service provided by MALINDO airline is associated with the passenger's satisfaction and customer loyalty.

This study also determine the significance of overall model that had been applied in Analysis of variance (ANOVA) table. Significant multiple $\mathrm{R}$ determines the overall strength of the relationship between the dependant and independent variables. It describes the amount of variation in the dependant variables clarified by the combination of the independent variables.

Moreover, in the Regression Coefficient table shows the significance value of each variable ranging from -1.00 to +1.00 . The significance level of 0.05 was apply in this study, therefore the variable was rejected if the statistical significance is below 0.05 . Besides, the beta was identified to measure of how strongly each predictor variables influences the criterion variable. The greater the beta value implies the greater the effect of the predictor variable on the criterion variable.

\subsection{Significant Level (P-value)}

The significance level defined as the criterion used for rejecting the null hypothesis. Significance level of 0.05 was applied in most of the analysis tools in this study. There are plenty of theories and principles were used to 
account for the use of $\mathrm{P}=0.05$ to denote statistical significance. The null hypothesis was rejected and the outcome is said to be statistically significant if the $\mathrm{P}$ value is less than or equal to the significance level. On the other hand, when $\mathrm{P}$ value is greater than 0.05 , the null hypothesis is accepted which the outcome is no significant.

\section{Results}

\subsection{Descriptive Results}

The data of the respondents' background consist of gender, age, education level, personal income level (RM), frequency of taking flight in a year, class of seats and the purpose of taking Malindo Airline. The frequency and percentage were used to analyse the respondents' profile.

\subsection{Demographic Data}

The following table shows the summary of the respondent's demographic data. The total number of respondents of this research is 200 respondents.

Table 3. Summary of respondents' demography

\begin{tabular}{|c|c|c|}
\hline Demography & Number of respondents & Percentage (\%) \\
\hline \multicolumn{3}{|l|}{ Gender } \\
\hline 1. Male & 125 & $62.5 \%$ \\
\hline Female & 75 & $37.5 \%$ \\
\hline \multicolumn{3}{|l|}{ Age } \\
\hline 1. 20 and below & 2 & $1 \%$ \\
\hline 21 to 29 & 36 & $8 \%$ \\
\hline 30 to 39 & 70 & $35 \%$ \\
\hline 40 to 49 & 64 & $32 \%$ \\
\hline 5. 50 and above & 28 & $14 \%$ \\
\hline \multicolumn{3}{|l|}{ Education Level } \\
\hline 1. Primary school and below & 6 & $3 \%$ \\
\hline Secondary school & 20 & $10 \%$ \\
\hline Diploma/STPM/ A-level & 42 & $21 \%$ \\
\hline Undergraduate & 97 & $48.5 \%$ \\
\hline 5. Postgraduate & 35 & $17.5 \%$ \\
\hline \multicolumn{3}{|l|}{ Personal Income Level (RM) } \\
\hline 1. Less than 1000 & 12 & $6 \%$ \\
\hline 1000 to 2999 & 32 & $16 \%$ \\
\hline 2000 to 4999 & 97 & $48.5 \%$ \\
\hline 5000 to 7999 & 40 & $30 \%$ \\
\hline 5. 8000 and above & 19 & $9.5 \%$ \\
\hline \multicolumn{3}{|l|}{ Frequency of flight in a year } \\
\hline 1. 1 to 5 times & 12 & $6 \%$ \\
\hline 6 to 10 times & 22 & $11 \%$ \\
\hline 11 to 15 times & 83 & $41.5 \%$ \\
\hline 16 to 20 times & 48 & $24 \%$ \\
\hline 5. 20 times and above & 35 & $17.5 \%$ \\
\hline \multicolumn{3}{|l|}{ Class of Seats } \\
\hline 1. Economy class & 170 & $85 \%$ \\
\hline Business class & 26 & $13 \%$ \\
\hline 3. First class & 4 & $2 \%$ \\
\hline \multicolumn{3}{|l|}{ Purpose of taking Malindo Flight } \\
\hline 1. Travelling & 25 & $12.5 \%$ \\
\hline 2. Business Trip & 42 & $21 \%$ \\
\hline 3. Company Outstation & 96 & $48 \%$ \\
\hline 4. Others & 37 & $18.5 \%$ \\
\hline
\end{tabular}

Table 3 shows the age of the respondents in this research. The age ranges from 20 and below, 21 to 29 years old, 30 to 39 years old, 40 to 49 years old and more than 50 years old. The highest number of respondents comes from the range of 30 to 39 years old, which are 70 respondents $(35 \%)$, followed by 40 to 49 years old with 64 respondents $(32 \%), 21$ to 29 years old with 36 respondents $(18 \%), 50$ and above with 28 respondents (14\%), and lastly 20 and below with 2 respondents (1\%).

Table 3 shows the education level of respondents in this research. The highest number of respondents are from the category of undergraduates, with 97 respondents $(48.5 \%)$, followed by diploma/stpm/a-level leavers with 42 respondents $(21 \%)$, postgraduates with 35 respondents $(17.5 \%)$, secondary school leavers with 20 respondents $(10 \%)$, and lastly primary school leavers with 6 respondents $(3 \%)$. 
Table 3 shows the personal income level of respondents in this research. Based on Table 3, there are 12 respondents' $(6 \%)$ income level are less than RM 1000 per month. Thirty two respondents (16\%) earns in the range of RM 1000 to RM 2999 per month. Ninety seven respondents (48.5\%) earns between RM 3000 to RM 4999 per month. Forty respondents (20\%) earn between RM 5000 to RM 7999 and lastly 19 respondents (9.5\%) earn more than RM 8000 per month.

Table 3 shows the chart of the frequency of flight taken by the respondents in a year. There are 12 respondents $(6 \%)$ who take 1 to 5 times of flight in a year, followed by 22 respondents (11\%) take 6 to 10 times of flight in year, 83 respondents (41.5\%) take 11 to 15 times of flight in year, 48 respondents (24\%) take 16 to 20 times of flight in a year, and lastly 35 respondents (17.5\%) take above 20 times of flight in a year.

Table 3 shows the type of seats taken by the respondents who participated in this research. Figure shows there are 170 respondents (85\%) takes economy class of seat, followed by 26 respondents (13\%) take business class and only 4 respondents (2\%) take first class flight.

Table 3 shows the purpose of respondents taking flight with Malindo Airline. It shows that the highest number of respondents which are 96 respondents (48\%) fly with Malindo Airline for the purpose of company outstation. It followed by 42 respondents (21\%) fly with Malindo Airline for the purpose of business trip, 37 respondents (18.5\%) fly with Malindo Airline for other reasons and lastly 25 respondents (12.5\%) fly with Malindo Airline for the purpose of travelling.

\subsection{Inferential Results}

Inferential statistical depicts the inferences or prediction on a certain population, which in this research refers to passenger's of Malindo Airline. A sample of 200 respondents were participated in this research to analyse the hypothesis of this research which was tested in this chapter.

\subsubsection{Test of relationship - Correlation}

Correlation analysis is used to show the strength of the relationship between two variables. According to Cohen (1988), Pearson correlation coefficient (r) shows the strength of the relationship between two variables, where 0.10 to 0.29 shows a weak relationship, 0.30 to 0.49 shows a medium relationship and 0.50 to 1.00 shows there is a strong relationship between the two variables. The range of Pearson correlation coefficient are from -1.00 to 1.00. Meanwhile, both directions shows the strength of the correlation, but in a different direction. As an example, $r$ value of 0.5 is equal to the value of -0.5 , but they are opposing meaning. The confidence level of the results was shown by the significance level which also named as Sig. (2-tailed) or $p$ (rho). The significance value has to be less than 0.05 to achieve high confidence level of the data.

Table 4. Correlation between independent and dependant variable for Malindo Airline

\begin{tabular}{|c|c|c|c|c|}
\hline & & $\begin{array}{c}\text { Mean for } \\
\text { Quality of service }\end{array}$ & $\begin{array}{c}\text { Mean for } \\
\text { Passenger's satisfaction }\end{array}$ & $\begin{array}{c}\text { Mean for } \\
\text { Customer Loyalty }\end{array}$ \\
\hline \multirow{3}{*}{ Mean_ServiceQuality } & Pearson Correlation & 1 & $.894^{* *}$ & $\mathbf{8 8 0}^{* *}$ \\
\hline & Sig. (2-tailed) & & .000 & .000 \\
\hline & $\mathrm{N}$ & 200 & 200 & 200 \\
\hline \multirow{3}{*}{ Mean_Passenger'satisfaction } & Pearson Correlation & $.894^{* *}$ & 1 & $.858^{* *}$ \\
\hline & Sig. (2-tailed) & .000 & & .000 \\
\hline & $\mathrm{N}$ & 200 & 200 & 200 \\
\hline \multirow{3}{*}{ Mean_CustomerLoyalty } & Pearson Correlation & $.880^{* *}$ & $.858^{* *}$ & 1 \\
\hline & Sig. (2-tailed) & .000 & .000 & \\
\hline & $\mathrm{N}$ & 200 & 200 & 200 \\
\hline
\end{tabular}

**. Correlation is significant at the 0.01 level (2-tailed).

Table 4 shows the correlation between independent variables which are quality of service and passenger's satisfaction towards customer loyalty towards Malindo Airline. Based on Table 4, it shows a positive relationship between quality of service (independent variable) and passenger's satisfaction (dependant variable), with $\mathrm{r}=0.894$ which shows a strong relationship and $\mathrm{p}=0.000$ showing $100 \%$ confidence level. Therefore, quality of service have positive relationship towards passenger's satisfaction of Malindo Airline's passenger's.

Based on Table 4, the relationship between passenger's satisfaction (independent variable) and customer loyalty (dependant variable) shows a positive relationship, with $\mathrm{r}=0.858$ which shows a strong relationship, and $\mathrm{p}=0.00$ showing $100 \%$ confidence level. Therefore, passenger's satisfaction has positive effect on customer loyalty towards Malindo Airline. 


\subsubsection{Test of Relationship - Multiple Regression}

Multiple regression is a technique that used to indicate the relationship between one dependent variable and several independent variables. According to Stevens (1996, p. 72), 15 subjects per predictor are needed for a reliable equation.

Table 5 (a). r-square

\begin{tabular}{llll}
\hline Model & R & R Square & Std. Error \\
\hline 1 & 0.894 & 0.799 & 0.36367 \\
\hline a Predictors: (Constant), Mean_cucstomer Satisfaction, Mean_Service Quality &
\end{tabular}

Table 5 (b). ANOVA ${ }^{\mathrm{b}}$

\begin{tabular}{cccccc}
\hline & Model & Sum of Squares & df & Mean Square & F \\
\hline \multirow{2}{*}{1} & Regression & 103.632 & 2 & 51.816 & $.000^{\mathrm{a}}$ \\
& Residual & 26.055 & 197 & .132 & \\
& Total & 129.687 & 199 & & \\
\hline
\end{tabular}

a. Predictors: (Constant), Mean_Passengers' satisfaction, Mean_Service Quality

b. Dependent Variable: Mean_Customer Loyalty

Table 5 (c). Multiple regression coefficients ${ }^{\mathrm{a}}$

\begin{tabular}{|c|c|c|c|c|c|c|}
\hline & \multirow{2}{*}{ Model } & \multicolumn{2}{|c|}{ Unstandardized Coefficients } & \multirow{2}{*}{$\begin{array}{c}\text { Standardized Coefficients } \\
\text { Beta } \\
\end{array}$} & \multirow{2}{*}{$\mathrm{t}$} & \multirow{2}{*}{ Sig. } \\
\hline & & $\mathrm{B}$ & Std. Error & & & \\
\hline \multirow{3}{*}{1} & (Constant) & .099 & .135 & & .734 & .464 \\
\hline & Mean_Service Quality & .656 & .083 & .562 & 7.872 & .000 \\
\hline & Mean_Passenger' satisfaction & .357 & .072 & .355 & 4.976 & .000 \\
\hline
\end{tabular}

a. Dependent Variable: Mean_Passengersatisfaction

Dependant variable (passenger's satisfaction) regression on independent variable (quality of service): Table 5 shows that in this test the dependant variable is passenger's satisfaction whereas quality of service is independent variable.

As shown in Table 5 (a), $\mathrm{R}^{2}=0.799$ was obtained, and it can be said that $79.9 \%$ of the dependant variable changes is explained by the model. Based on Table 5 (b), a significant model emerged; $F=391.779, p<0.005$. Based on Table 5 (c), quality of service and passenger's satisfaction are significant. As a result, passenger's satisfaction directly affected by the quality of service provided by Malindo Airline.

\section{Conclusion and Recommendations}

\subsection{The Effect of Quality of Service on Passenger's Satisfaction among Passenger's of Malindo Airline}

In this research, there are several quality of service dimensions that affect the passenger's satisfaction of the passenger's of Malindo Airline. Among the quality of service dimensions are tangible, reliability, responsiveness, assurance and empathy. In order to identify if there is a relationship between the independent variables and dependant variable, correlation analysis was conducted.

Based on Table 4, it shows there is a positive relationship between quality of service (tangible, reliability, responsiveness, assurance and empathy) with passenger's satisfaction of passenger's towards Malindo Airline, with correlation coefficient score of 0.894 . This shows that quality of service has strong relationship and it does effect the passenger's satisfaction of the passenger's of Malindo Airline.

Numerous studies have indicated that there are positive relationship between quality of service and passenger's satisfaction (Cronin \& Taylor, 1992). In short, factors of quality of service such as tangibility, reliability, responsiveness, assurance and empathy affects the passenger's satisfaction towards Malindo Airline. Thus, the objectives of this research was achieved where quality of service (tangibility, reliability, responsiveness, assurance, empathy) has relationship towards passenger's satisfaction among passenger's of Malindo Airline.

Upon clarified that quality of service has impact on passenger's satisfaction, it is vital to identify whether passenger's satisfaction has impact on customer loyalty among passenger's towards Malindo Airline. Pearson correlation coefficient analysis is used to test the relationship between independent variable (quality of service) and dependant variable (passenger's satisfaction). 
The results further support the reviews of previous researches as in literature review. According to Iacobucci, Ostrom, and Grayson, (1995), customers (passenger's satisfaction) are an important determinant of repurchase intention and customer loyalty. Therefore, high passenger's satisfaction will turn into high customer loyalty (Iacobucci, Ostrom, \& Grayson, 1995).

Thus, the objectives of this research, was determined that tangibility, reliability, responsiveness, assurance and empathy have positive relationship towards passenger's satisfaction among the passenger's of Malindo Airline.

\subsection{Limitations of the Study}

There were several limitations during the process of conducting this research. The corporation of the respondents is the major problem in conducting the survey. Apart from that, it is hard to ensure the particular person is passenger of Malindo Airline. Air Asia has become the number one low cost airline in Malaysia resulted most of the passenger's in KLIA 2 are Air Asia passenger's.

Moreover, there are more than 30 incomplete questionnaires was given back by the respondents resulted in the lesser data collected. Lastly, it is hard to get respondents in Senai Airport, Johor Bahru who take Malindo Airline. This causes the need to traveling to Kuala Lumpur to run the survey.

\subsection{Recommendation for Business}

This section provides recommendation for future businesses and marketers based on results achieved from this research. The results obtained could help companies to make the improvement on quality of service and development of passenger's satisfaction and customer loyalty.

According to the results of this study, it seems that passengers of Malindo Airline take quality of service as an important factor throughout their flight to retain their loyalty towards Malindo Airline. Malindo Airline has several competitors in the low cost airline industry, therefore, in order for it to be competitive, Malindo Airline needs to improve on their quality of service provided to retain customer loyalty by increasing the passenger's satisfaction of their passenger's. Consumers were able to evaluate value for money.

\subsection{Recommendation for Future Research}

There are several limitations that the researcher faced throughout the process of this research. Below are few suggestions for future research to solve those limitations.

i. The respondents of this research are selected according to convenience of the researcher (convenience sampling). These results are uneven sample distribution for certain categorical data. Thus, it is recommended that future researchers identify the number of respondents to ensure equal distribution in the demographic data.

ii. The total number of respondents for this research is 200 respondents of Malindo Airline passengers. However, it is best to have at least 500 of respondents to conclude a more accurate result about the whole population. Thus, it is recommended that future researchers expand the number of respondents for this study.

\subsection{Conclusion}

In a conclusion, the main objective of this research is to study the relationship between quality of service, passenger's satisfaction and customer loyalty among passengers of Malindo Airline. Based on statistical analysis, it was found that quality of service (tangibility, reliability, responsiveness, assurance and empathy) affects the passenger's satisfaction of Malindo Airline passengers. It seems that although Malindo Airline is new in the low cost airline industry, yet quality of service is the main factor that affect the passenger's satisfaction and customer loyalty towards an airline company. Generally, low cost airline passengers not only opt for cheapest ticket price but also look into the service provided by the airline company. Malindo Airline should consider this and provide better service for the people, to be competitive in the low cost airline industry.

\section{References}

Anderson, E. W., Fornell, C., \& Lehman, D. R. (1994). Customer Satisfaction, Market Share, and Profitability: Findings from Sweden. Journal of Marketing, 58, 53-66. http://dx.doi.org/10.2307/1252310

Boulding, W., Staelin, R., Kalra, A., \& Zeithaml, V. (1993). A Dynamic Process Model of Service Quality: From expectation to behavioral intentions. Journal of Marketing Research, 30, 7-27. http://dx.doi.org/10.2307/ 3172510

Brown, T. J., Churchill, G. A. Jr., \& Peter, J. P. (1993). Tracking the Evolution of the Services Marketing Literature. Journal of Retailing, 69, 61-103. http://dx.doi.org/10.1016/S0022-4359(05)80004-1 
Cardozo, R. N. (1965). An Experimental Study of Consumer Effort, Expectation and Satisfaction. Journal of Marketing Research, 2(August), 244-249. http://dx.doi.org/10.2307/3150182

Chen, M. K. (1995). The People Choose the Place Attitude of the Movement and Participate in Behavioral Analysis-Take Heated Swimming Pool of Room of Taizhong as an Example. Hsiung-Ta Sportsl of Journal, 5, 35-65.

Creswell. (2003). Research Design: Qualitative, Quantitative, and Mixed Method Approaches (Vol. 2, 2nd ed.). Thousand Oaks, Calif.: Sage Publication.

Cronin, J. J., \& Taylor, S. A. (1992). Measuring Service Quality: A reexamination and extension. Journal of Marking, 56, 55-68. http://dx.doi.org/10.2307/1252296

Dabholkar, P. A., Thorpe, D. 1., \& Rentz, J. O. (1996). A Measure of Service Quality for Retail Stores: Scale Development and Validation. Journal of the Academy of Marketing Science, 24, 3-16. http://dx.doi.org/10. 1007/BF02893933

Hair, R. L., Tatham, R. E., Anderson, \& Black, W. (1998). Multivariate Data Analysis (5th ed.). Upper Saddle River, N.J.: Prentice Hall.

Ho, H. T. (2004). The Construction of the Quality Evaluation Model for Sport and Health Club (Unpublished Master Dissertation). National Taiwan college of Physical education, Taichung, Taiwan.

Iacobucci, D., Ostrom, A., \& Grayson, K. (1995). Distinguishing Service Quality andCustomer Satisfaction: The voice of the customer satisfaction. Journal of Consumer Psychology, 4(3), 277-303. http://dx.doi.org/ 10.1207/s15327663jcp0403_04

Johnson, M. D., \& Fornell, C. (1991). A Framework for Comparing Customer SatisfactionAcross Individuals and Product Categories. Journal of Economic Psychology, 12(2), 267-286. http://dx.doi.org/10.1016/01674870(91)90016-M

Johnson, R. L., Tsiros, M., \& Lancioni, R. A. (1995). Measuring Service Quality: A Systems Approach. The Journal of Services Marketing, 9(5), 6-20. http://dx.doi.org/10.1108/08876049510100272

Kotler, P. (2010). Marketing Management: Analysis, Planning, Implementation and Control. Englewood Cliffs New Jersey: Prentice-Hall Inc.

Kotler, P., \& Gary, A. (1999). Principles of marketing. New Jersey: Prentice-Hall Inc.

Kouthouris, C., \& Alexandris, K. (2005). Can Service Quality Predict Customer Satisfaction and Behavioral Intentions in the Sport Tourism Industry? An application of the SERVQUAL model in an outdoor setting. Journal of Sport Tourism, 10(2), 101-111. http://dx.doi.org/10.1080/14775080500223165

Krejcie, R. V., \& Morgan, D. W. (1970). Determining sample size for research activities. EducPsychol Meas.

Lehtinen, U., \& Lehtinen, J. R. (1991). Two Approaches to Service Quality Dimensions. The Service Industries Journal, 11(3), 287-303. http://dx.doi.org/10.1080/02642069100000047

Liang, W. W. (2001). The Relation of Customer Direction, Service Compensation and Service Quality Study-Using the Sample from International Tourism Hotel (Unpublished Master Dissertation). National Cheng Kung University, Tainan, Taiwan.

Lin, H.-Y. (2010). The Study of Exercise Participation Motivation and the Relationship among Service Quality, Customer Satisfaction and, Customer Loyalty at Selected Fitness Health Clubs in Taipei City, Taiwan. United States Sport Academy (PhD Thesis).

Lin, P. Y. (2004). Research of Service Quality, Customer Satisfaction, and Customer Loyalty in Taipei Sports Center (Master Dissertation). National Pingtung University of Education, Pingtung, Taiwan.

Mitra, A. (1993). Fundamentals of Quality Control and Improvement. New York: Macmillan

Novikova, K. (2006). A Study of customer satisfaction factors and customer satisfaction in the hospitality industry (B.S. Thesis). Voronezh State University

Oliver, R. L., \& DeSarbo, W. S. (1988). Response Determinants in Satisfaction Judgments. Journal of Consumer Research, 14, 495-507. http://dx.doi.org/10.1086/209131

Oliver, R. L. (1977). Effects of Expectations and Disconfirmation on Post explosure Product Evaluation. Journal of Applied Psychology, 62, 246-250. http://dx.doi.org/10.1037/0021-9010.62.4.480

Oliver, R. L. (1980). A Cognitive Model ofthe Antecedents and Consequences of Satisfaction Decision. Journal 
of Marketing Research, 17, 460-469. http://dx.doi.org/10.2307/3150499

Oliver, R. L. (1993). A Conceptual Model of Service Quality and Customer Satisfaction: Compatible goals, different concepts. Advances in Services Marketing and Management, 2, 65-85.

Oliver, R. L., \& DeSarbo, W. S. (1988). Response Determinants in Satisfaction Judgments. Journal of Consumer Research, 14, 495-507. http://dx.doi.org/10.1086/209131

Parasuraman, A., Ziethaml, V., \& Berry, L. L. (1985). A Conceptual Model of Service Quality and its Implication for Future Research. Journal of Marketing, 49, 41-50. http://dx.doi.org/10.2307/1251430

Reichheld, F., \& Sasser, W. E. (1990). Zero Defections: Quality comes to services. Harvard Business Review, 68(Sep. /Oct.), 105-111.

Rust, R. T., \& Oliver, R. L. (1994). Service Quality: Insights and Managerial Implications from the Frontier. Service Quality: New Directions in Theory and Practice. New York: Sage Publications, Inc., 1-19. http://dx.doi.org/10.4135/9781452229102.n1

Sasser, W. E., Olsen, R. P., \& Wyckoff, D. D. (1978). Management of Service Operations: Text and Cases. Boston: Allyn and Bacon.

Su, W. L. (2000). Research of Hospitalize Service Quality and Patient Satisfy-Using the Samples of Cheng-Kung and Ji-Mei Hospital (Unpublished Master Dissertation). National Cheng-Kung University, Tainan, Taiwan.

Tian-Cole, S., \& Crompton, J. (2003). A Conceptualization of the Relationship between Service Quality and Visitor Satisfaction, and Their Links to Destination Selection. Leisure Studies, 22, 65-80. http://dx.doi.org/10.1080/02614360306572

Tseng, K. H. (2004). Marketing Management: Theory Analysis and Practical Application. Taiwan, Taipei: Qian-Cheng Industry Publication.

Wang, C. S. (2002). A Study on Customer Satisfaction of Service Quality in Home Appliance Retail Business (Master Dissertation). Yi-Shou University, Kaohsiung, Taiwan.

Weng, C. H. (1998). A Study on the Service Quality of Legal Service in Taiwan. National Taiwan University, Report on Executive National science commission project study.

Woodside, A. G., Frey, L. L., \& Daly, R. T. (1989). Linking Service Quality, Customer Satisfaction, and Behavioral Intention. Journal of Health Care Marketing, 9, 5-17.

Yu, C. J. (2002). The Study of the Service Quality and Satisfaction of YMCA Sports and Leisure Curriculum (Unpublished Master Dissertation). Chao-Yang University of Technology, Taichung, Taiwan

\section{Copyrights}

Copyright for this article is retained by the author(s), with first publication rights granted to the journal.

This is an open-access article distributed under the terms and conditions of the Creative Commons Attribution license (http://creativecommons.org/licenses/by/3.0/). 